\title{
"Employee engagement: An illusive force of motivation and emotional commitment of employees to the organization and its goals."
}

\author{
Dr. Almas Sabir ${ }^{1}$, Dr. Arisha Fatima Rizvi ${ }^{2}$ \\ ${ }^{1}$ Lecturer, University of Hail, Kingdom of Saudi Arabia \\ ${ }^{2}$ Asst. Professor, University of Hail, Kingdom of Saudi Arabia \\ almas.sabir083@gmail.com
}

Abstract: Engagement is a universal priority for organizations today. Companies want engaged workers. It's good for the company and good for those who work there. A workplace that values employee engagement is a humane workplace that nurtures the best in each individual. This article investigated the employee's engagement in different organizations.

This study will provide a deep insight into what the average employee feels is important and what impact is there in motivation to remain loyal and committed to their current company, organization, association, job or any position. Most employees remain loyal and committed to their employers because of diverse motivational factors which include belief in the mission and vision; due to job security; because of job satisfaction, because of the work environment; promotion potential; pay and benefits; and recognition. Through qualitative interviews, I examined employee perceptions of job satisfaction and whether the presence or absence of training and supervisory factors might impact their motivation to remain loyal and committed to an employer.

This paper concludes with thoughts about the measurement of the 4 facets of engagement and potential antecedents, especially measurement via online employee surveys. Survey contains a subset of research based anchor questions that are designed to measure overall engagement.

Keywords: Engagement, worlplace, employee satisfaction, performance goals.

\section{INTRODUCTION}

Employee Engagement is a workplace approach resulting in the right conditions for all members of an organization to give their best each day. Employee Engagement is based on trust, integrity, a two-way commitment and communication between an organization and its members. It is an approach that increases the chances of business success, contributing to organizational and individual performance, productivity and well-being.

\section{EMployeE Engagement Consists of AT LEAST THREE ElEMENTS}

1. Employee's emotional state.

2. Mutually beneficial employee-employer relationship.

3. Increased employee ability to achieve performance goals.

From an employer's point of view, employee engagement is concerned with using new measures and initiatives to increase the positive emotional attachment felt and therefore productivity and overall business success. An engaged workforce produces better business results, does not hop jobs and more importantly, is an ambassador of the organization at all points of time. 
“Employee engagement: An illusive force of motivation and emotional commitment of employees to the organization and its goals."

Engaged employees are perceived to form a part of an organization's brand and an engaged, happy workforce can have a knock-on effect on customer retention, recruitment of key talent and the ability to attract new customers in a world where a company's values are crucial to the consumers.

\section{EMPLOYEe Recognition - A Vital Tool}

Employee recognition is a vital tool which allows companies to drive measureable business results, inspire your employees and retain your top talent.

A dynamic, agile and customizable platform allows easily accessible recognition programmes tailored to the needs and identity of business. A diverse selection of functions is available, allowing for manager-employee and peer-to-peer recognition.

The opportunity to both thank colleagues and be thanked by peers and managers alike strengthens morale, and creates emotional ties to the organization.

Studies have shown that up to $79 \%$ of employees feel that recognition gives them a stronger sense of the company's goals and objectives. With this understanding, and a sense of being recognized for their good behavior and achievements, employee engagement increases by almost 60\%, according to Towers Watson.

This creates a scenario where the employees are responsible for their own company culture. This is an essential strategy for reducing turnover and retaining your top employees. According to research from Bersin by Deloitte, the employment of an effective recognition program me lowers turnover rates by $31 \%$.

This not only secures the retaining of your top performers, but motivates the mid-to-high level performers to stay and engage even more passionately. A study by Glob force and SHRM showed a 32\% increase in productivity for companies that practice peer-to-peer recognition.

\section{What recognition ultimately translates into is increased engagement and productivity, which} in turn results in higher profitability

Organizations have come to realize that in today's constantly changing business scenario, the most valuable resource that needs to be leveraged is human resource. This means not just attracting and retaining them but keeping them motivated and committed to achieving the organization goals.

As it is an established fact that there is a clear link between organizational performance and employee engagement, every organization seeking sustenance and growth in the ever changing world of work quickly respond to the needs of employees along with designing and implementing a customized process to increase the levels of employee engagement.

\section{EMPLOYEE EngAGEMENT - A VALUEd INPUT}

Employee engagement is directly tied to employees' sense of value and the ability to give feedback about working conditions and their workplace relationships, particularly those involving employee-supervisor interaction. Therefore, an effective strategic includes developing an employee opinion survey or enabling another method for employees to voice their opinions and concerns. The most important component of an employee opinion survey is an action plan, which can be another factor in the employee engagement strategy. Involving employees in action plan steps provides another outlet for employee engagement. The following are a few basic steps in this process based on the best industry practices. 
“Employee engagement: An illusive force of motivation and emotional commitment of employees to the organization and its goals."

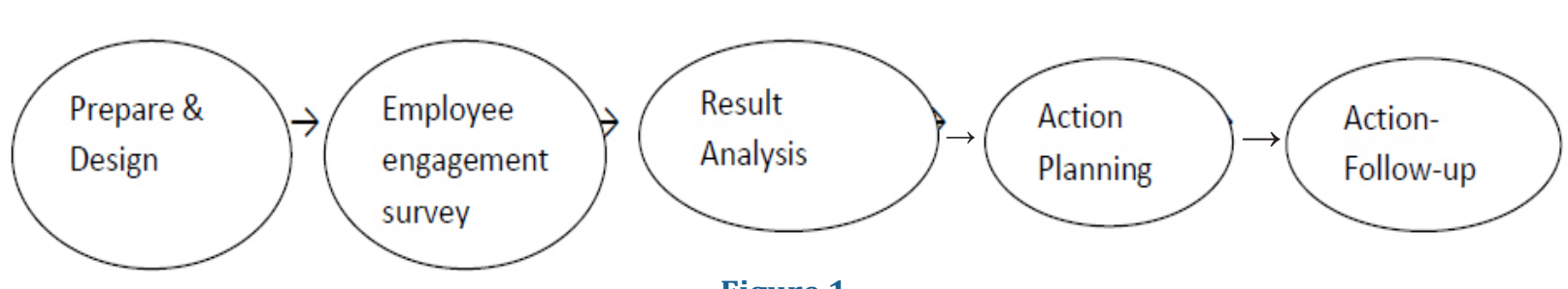

Figure 1

Prepare and Design

The first step in the process is about discovering the specific requirements of your organization and deciding the priorities. After that a customised design of carrying the whole process can be designed. It is recommended to seek advice of expert management consultant in order to increase the chances of getting it done right at the first attempt.

\section{Employee Engagement Survey}

Design the questions of the employee engagement survey and deploy it with the help of an appropriate media. It can be either in printed form or set online depending upon the comfort level of the employees and your questionnaire evaluation process.

\section{Result Analysis}

It is the most important step in the entire process. It is time when reports are to be analyzed to find out what exactly motivates employees to perform their best and what actually disengages them and finally compels them to leave the organization. The results and information can then be delivered through presentations.

\section{Action Planning}

How to turn the results of the survey in to an action' is a challenging question that organizations need to deal with the utmost care. Coaching of line managers as well as HR professionals is very important in order to tell them how to take appropriate actions to engage employees. They should also be told about do's and don'ts so that they can successfully implement the changes.

\section{Action Follow-up}

Action follow up is necessary in order to find out if the action has been taken in the right direction or not and if it is producing the desired results.

\section{RESEARCH METHODS}

A random sample of 160 employees belonging to different professional groupings was obtained from online survey that included all types of employees. Rating scale is used for question types. As there are many definitions of engagement in use, there are also many different measures of engagement. Typically a measure of engagement will ask respondents to rate a number of questionnaire statements, according to how much they agreed or disagree with them or how frequently they experience the feeling or thought each statement refers to. Participants are asked 16 questions on a six-point rating scale from 'strongly disagree' to 'strongly agree'.

\section{The Employee Engagement survey uses the following 6-point scale in questionnaire}

1. Very Disagreeable

2. Disagreeable 
“Employee engagement: An illusive force of motivation and emotional commitment of employees to the organization and its goals."

3. Somewhat Disagreeable

4. Somewhat Agreeable

5. Agreeable

6. Very Agreeable

A two-page survey was also mailed to certain employees using an internal mail system in December 2017. The survey was previously piloted among several groups of different department professionals. Questions in the survey asked whether employees use tools and resources for the job, work is valued by the organization or not, training is provided or not and how the expected amount of work is given, how often the people they work with take accountability and ownership for results are given to find information.

The survey was completely anonymous and only collected limited data (job, results, training and amount of work) to assess the representativeness and engagement of the respondents. Two reminder mailings were conducted to improve the response rate, before the response collection period ended in December 2017.

\section{RESEARCH Findings (SuRVey)}

Feeling valued is an important piece of the employee's assessment of their workplace. Those who feel valued are more likely to report being and feeling motivated to do their very best for their employer whereas those who do not feel valued are less likely to recommend their place of work to others and more likely to report wanting to find a new job in the future.

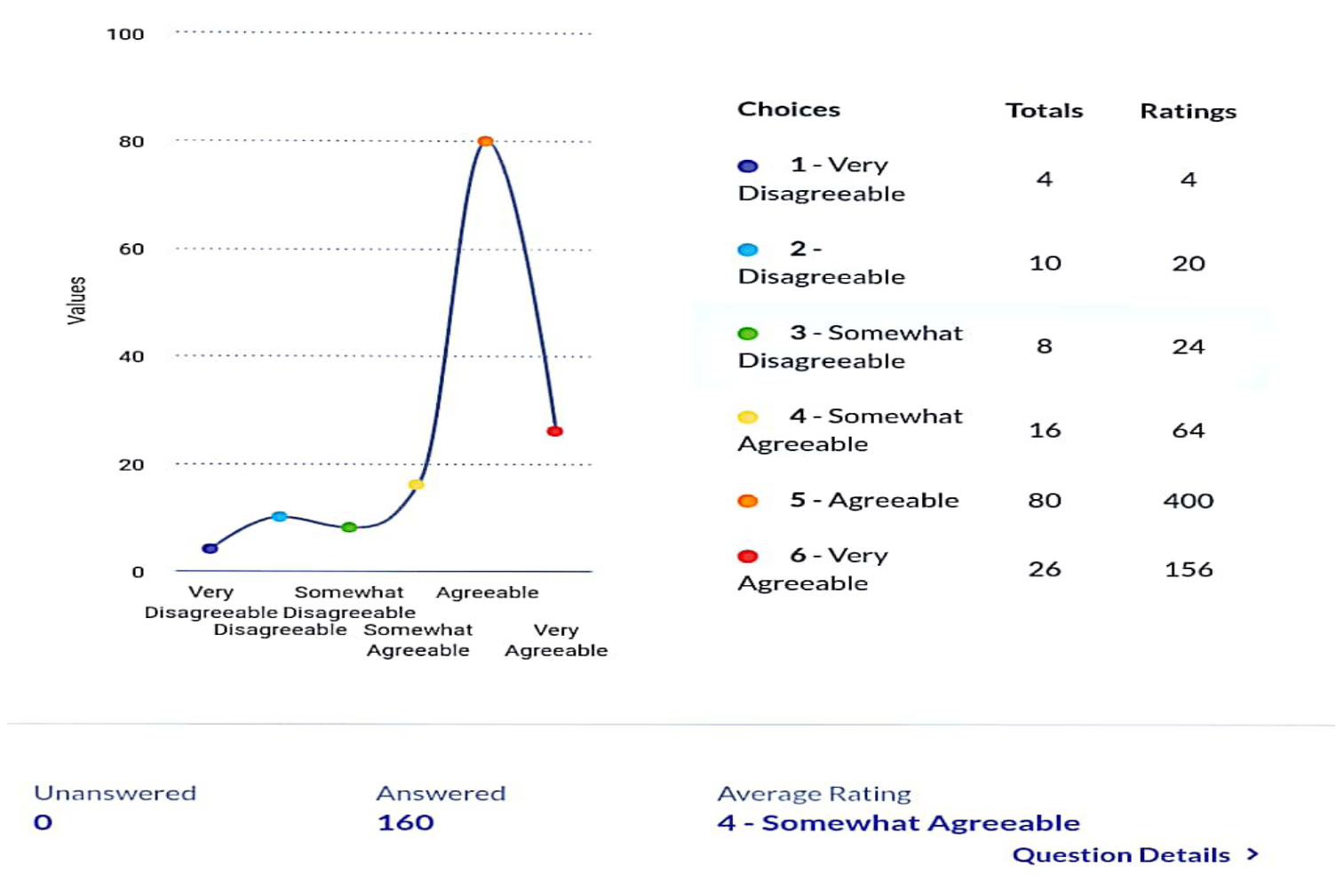

Fig1. Respondents work valued by the organization 
“Employee engagement: An illusive force of motivation and emotional commitment of employees to the organization and its goals."

Employees who report feeling valued by their employer are significantly more likely to report they are motivated to do their very best for their employer (with 400 rating with 80 respondents).

- They are also more likely to report they would recommend their workplace to others.

- On the other hand, those who do not feel valued are significantly more likely to report that they intend to seek employment outside of their company or they want to leave the company.

Only 68 out of 160 respondents reported receiving training in their organizations (Figure: 2)

For training to have real value, company must first have a clear strategy and execution plan in place. Strategy should clearly articulate three to five core skills and competencies and three to five key activities that will make execution possible. Training should then focus on these skills and competencies. Otherwise, it is probably just a nice idea from a pushy trainer, your HR department or a line manager.

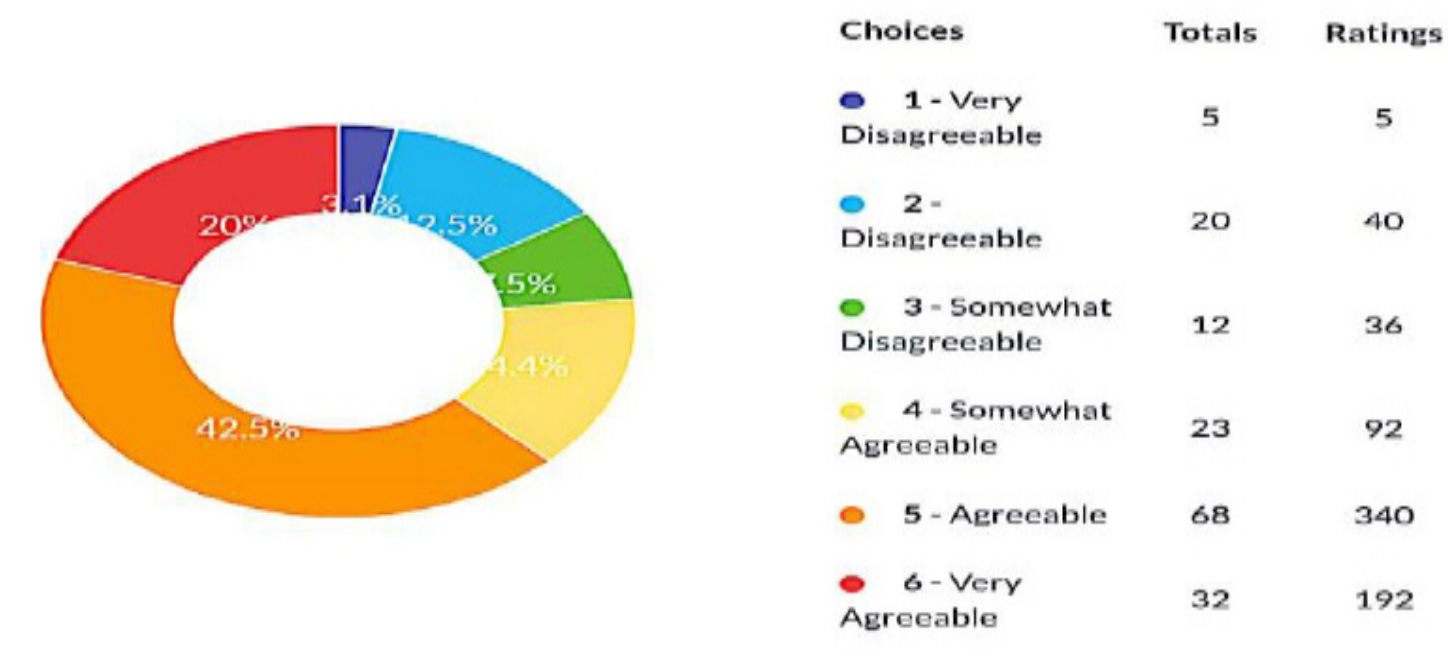
Unanswered
O
Answered
160
Average Rating
4 - Somewhat Agreeable
Question Details >

Fig2. Respondents received training for their job

- Respondents are somewhat agree for receiving training in their organizations.

- Some companies derail their training programs by training their teams in painfully boring marathon sessions. The most effective training is done in short bites.

Employee Attitude surveys provides a picture of organization's needs. This survey can be used to solicit employee opinions on a variety of issues such as the company's success in communicating its mission to employees, or local issues such as quality of the working environment.(Figure: 3 ) 
"Employee engagement: An illusive force of motivation and emotional commitment of employees to the organization and its goals."

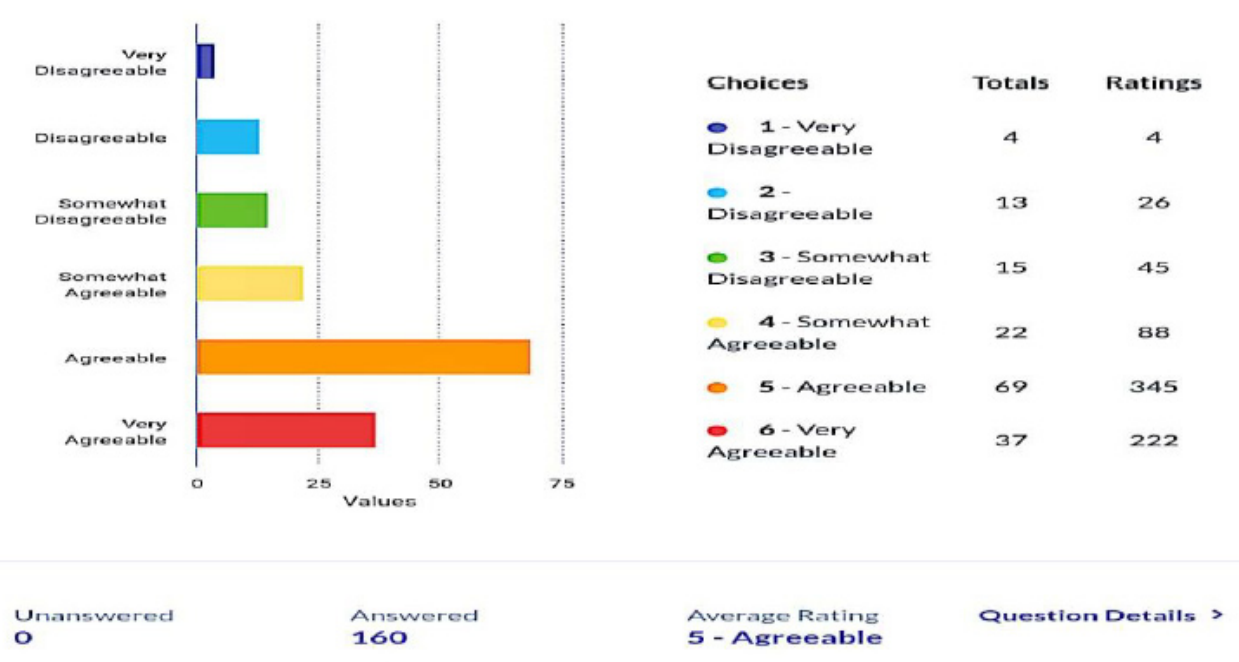

Fig3. Supervisors understanding of respondents work in organization

According to results, 69 respondents are strongly agreed that supervisors help their employees to understand their work and their importance in organization. According to them supervisory tasks should include-

- Helping the team understand performance targets and goals.

- Training or ensuring that workers are properly trained for their specific roles.

- Scheduling work hours and shifts.

- Coordinating job rotation and cross-training.

The supervisor is often responsible to represent the employee's requests and to management, along with also representing the employee's case for deserving a reward.

Perception is a very real issue for leaders. They must decide how they want employees to view them and act accordingly. Employees who feel valued and appreciated by their leaders are infinitely more likely to go above and beyond for the company and hold themselves accountable for their part of a project. (Figure: 4)

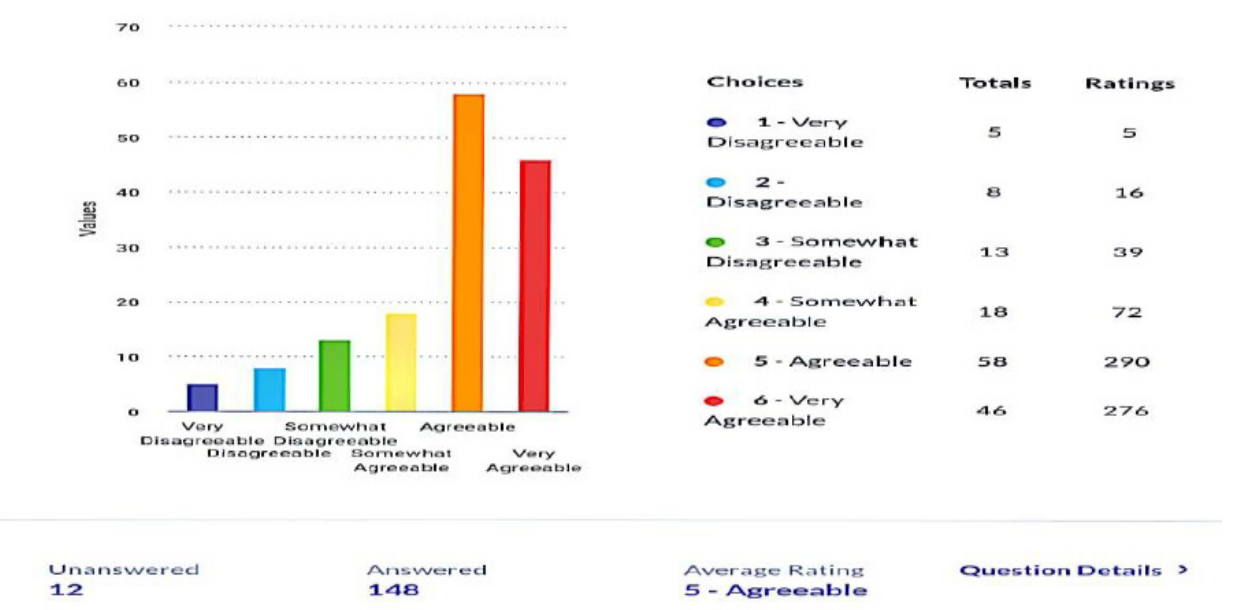

Fig4. Organization care about employees (Respondents view) 
"Employee engagement: An illusive force of motivation and emotional commitment of employees to the organization and its goals."

According to survey analysis(Figure: 4) majority of respondents strongly agreed that an employee is more likely to give his best when advancement opportunities exist and he can see a bright future with the company, instead of working day-in-and-day-out in a position that offers no chance to excel or advance.

\begin{tabular}{|c|c|c|c|c|c|c|c|}
\hline S.No. & Question & \begin{tabular}{c|} 
Very \\
Disagreeable \\
\end{tabular} & Disagreeable & $\begin{array}{c}\text { Somewhat } \\
\text { Disagreeable }\end{array}$ & $\begin{array}{l}\text { Somewhat } \\
\text { Agreeable } \\
\end{array}$ & Agreeable & $\begin{array}{c}\text { Very } \\
\text { Agreeable }\end{array}$ \\
\hline 1 & $\begin{array}{l}\text { I have the tools and resources I } \\
\text { need to do my job well. }\end{array}$ & 7 & 21 & 16 & 15 & 72 & 29 \\
\hline 2 & $\begin{array}{l}\text { Most days, I see positive results } \\
\text { because of my work. }\end{array}$ & 3 & 14 & 11 & 25 & 79 & 28 \\
\hline 3 & $\begin{array}{l}\text { My work is valued by this } \\
\text { organization. }\end{array}$ & 4 & 10 & 8 & 16 & 80 & 26 \\
\hline 4 & $\begin{array}{l}\text { I have received the training I } \\
\text { need to do my job well. }\end{array}$ & 5 & 20 & 12 & 23 & 68 & 32 \\
\hline 5 & $\begin{array}{l}\text { The amount of work I am } \\
\text { expected to do is reasonable. }\end{array}$ & 4 & 16 & 15 & 21 & 71 & 33 \\
\hline 6 & $\begin{array}{l}\text { The people I work with take } \\
\text { accountability and ownership for } \\
\text { results. }\end{array}$ & 6 & 11 & 16 & 28 & 65 & 34 \\
\hline 7 & $\begin{array}{l}\text { The people I work with take } \\
\text { accountability and ownership for } \\
\text { results. }\end{array}$ & 2 & 5 & 8 & 27 & 68 & 38 \\
\hline 8 & $\begin{array}{l}\text { My coworkers and I openly talk } \\
\text { about what needs to be done to } \\
\text { be more effective. }\end{array}$ & 4 & 17 & 10 & 20 & 67 & 38 \\
\hline 9 & $\begin{array}{l}\text { My supervisor helps me } \\
\text { understand how my work is } \\
\text { important to the organization. }\end{array}$ & 4 & 13 & 15 & 22 & 69 & 37 \\
\hline 10 & $\begin{array}{l}\text { My supervisor is approachable } \\
\text { and easy to talk to. }\end{array}$ & 1 & 10 & 12 & 32 & 63 & 42 \\
\hline 11 & $\begin{array}{l}\text { My supervisor creates a } \\
\text { motivating and energizing } \\
\text { workplace. }\end{array}$ & 1 & 7 & 18 & 22 & 71 & 32 \\
\hline 12 & $\begin{array}{l}\text { My supervisor sets high } \\
\text { expectations for our team's } \\
\text { performance. }\end{array}$ & 5 & 12 & 11 & 25 & 69 & 38 \\
\hline 13 & $\begin{array}{l}\text { The vision and goals of this } \\
\text { organization are important to me } \\
\text { personally. }\end{array}$ & 6 & 12 & 8 & 40 & 59 & 35 \\
\hline 14 & $\begin{array}{l}\text { This organization provides } \\
\text { attractive opportunities for } \\
\text { training and development. }\end{array}$ & 3 & 15 & 11 & 26 & 70 & 35 \\
\hline 15 & $\begin{array}{l}\text { This organization cares about } \\
\text { employees. }\end{array}$ & 5 & 8 & 13 & 18 & 58 & 46 \\
\hline 16 & $\begin{array}{l}\text { I would recommend this } \\
\text { organization as a great place to } \\
\text { work. }\end{array}$ & 2 & 14 & 14 & 27 & 69 & 34 \\
\hline
\end{tabular}

Fig5. Overall Analysis of the survey 
"Employee engagement: An illusive force of motivation and emotional commitment of employees to the organization and its goals."

\section{CONCLUSION}

Organize employee recognition events, such as employee-of-the-month awards or more expanded annual award ceremonies, to recognize employees who excel and give more than necessary to everyday job duties. An employee is more likely to take pride in his job and feel valued by the company when individual achievements are recognized and celebrated by managers.

The key to make this transition is to begin thinking about employee satisfaction. A great approach to this might be treating your employees as if they are your internal customers. This means moving beyond cheesy motivational posters and half-hearted spirit meetings. Today, some of the most successful companies are truly engaging their employees by applying many of the same philosophies and business practices used to enhance satisfaction with their external customers.

Last but not the least one of the most important places to start implementing this approach is with technology. Workers are also consumers who have been conditioned to expect 24/7-access to product information, service, and support. They've grown accustomed to interactive, self-service options that enable them to find information on their own.

Before employees will believe in, or care about, the long-term vision of the company, its culture, or its success, they need to feel that you see each of them as a person — not just an "employee" to execute your to-do list. They need to feel that their leader — and the company — are invested in them. Once you show your team how much you value them, there's nothing they won't strive to accomplish.

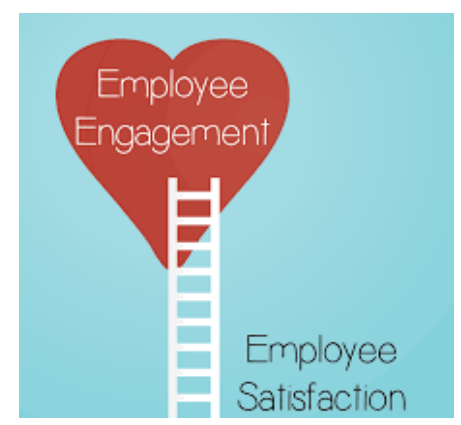

The Survey Questionnaire contains a subset of research-based anchor questions that are designed to measure overall engagement. The other questions measure the factors that drive engagement and satisfaction in an organization. The survey is completely customizable to the needs of every organization and employee.

\begin{tabular}{|c|c|c|c|c|c|}
\hline \multicolumn{6}{|c|}{ Q1. I have the tools and resources I need to do my job well. } \\
\hline $\begin{array}{c}\text { Very } \\
\text { Disagreeable } \\
\end{array}$ & Disagreeable & $\begin{array}{c}\text { Somewhat } \\
\text { Disagreeable }\end{array}$ & $\begin{array}{l}\text { Somewhat } \\
\text { Agreeable }\end{array}$ & Agreeable & Very Agreeable \\
\hline $\mathrm{O}$ & O & O & O & $\mathrm{O}$ & $\mathrm{O}$ \\
\hline \multicolumn{6}{|c|}{ Q2.Most days, I see positive results because of my work. } \\
\hline $\begin{array}{c}\text { Very } \\
\text { Disagreeable }\end{array}$ & Disagreeable & $\begin{array}{c}\text { Somewhat } \\
\text { Disagreeable }\end{array}$ & $\begin{array}{l}\text { Somewhat } \\
\text { Agreeable }\end{array}$ & Agreeable & Very Agreeable \\
\hline $\mathrm{O}$ & $\mathrm{O}$ & O & O & $\mathrm{O}$ & O \\
\hline \multicolumn{6}{|c|}{ Q3. My work is valued by this organization. } \\
\hline $\begin{array}{c}\text { Very } \\
\text { Disagreeable }\end{array}$ & Disagreeable & $\begin{array}{c}\text { Somewhat } \\
\text { Disagreeable }\end{array}$ & $\begin{array}{l}\text { Somewhat } \\
\text { Agreeable }\end{array}$ & Agreeable & Very Agreeable \\
\hline
\end{tabular}

American Research Journal of Business and Management

Page 8 
“Employee engagement: An illusive force of motivation and emotional commitment of employees to the organization and its goals."

\begin{tabular}{|c|c|c|c|c|c|}
\hline O & O & O & O & $\mathrm{O}$ & $\mathrm{O}$ \\
\hline \multicolumn{6}{|c|}{ Q4. I have received the training I need to do my job well. } \\
\hline $\begin{array}{c}\text { Very } \\
\text { Disagreeable } \\
\end{array}$ & Disagreeable & $\begin{array}{c}\text { Somewhat } \\
\text { Disagreeable }\end{array}$ & $\begin{array}{l}\text { Somewhat } \\
\text { Agreeable }\end{array}$ & Agreeable & Very Agreeable \\
\hline O & O & O & O & O & O \\
\hline \multicolumn{6}{|c|}{ Q5. The amount of work I am expected to do is reasonable. } \\
\hline $\begin{array}{c}\text { Very } \\
\text { Disagreeable }\end{array}$ & Disagreeable & $\begin{array}{c}\text { Somewhat } \\
\text { Disagreeable }\end{array}$ & $\begin{array}{l}\text { Somewhat } \\
\text { Agreeable }\end{array}$ & Agreeable & Very Agreeable \\
\hline O & O & O & O & O & O \\
\hline \multicolumn{6}{|c|}{ Q6. The people I work with take accountability and ownership for results. } \\
\hline $\begin{array}{c}\text { Very } \\
\text { Disagreeable }\end{array}$ & Disagreeable & $\begin{array}{c}\text { Somewhat } \\
\text { Disagreeable }\end{array}$ & $\begin{array}{l}\text { Somewhat } \\
\text { Agreeable }\end{array}$ & Agreeable & Very Agreeable \\
\hline O & O & O & $\mathrm{O}$ & O & O \\
\hline \multicolumn{6}{|c|}{ Q7.The people I work with take accountability and ownership for results. } \\
\hline $\begin{array}{c}\text { Very } \\
\text { Disagreeable }\end{array}$ & Disagreeable & $\begin{array}{c}\text { Somewhat } \\
\text { Disagreeable }\end{array}$ & $\begin{array}{l}\text { Somewhat } \\
\text { Agreeable }\end{array}$ & Agreeable & Very Agreeable \\
\hline O & O & O & O & O & O \\
\hline \multicolumn{6}{|c|}{ Q8.My coworkers and I openly talk about what needs to be done to be more effective. } \\
\hline $\begin{array}{c}\text { Very } \\
\text { Disagreeable }\end{array}$ & Disagreeable & $\begin{array}{c}\text { Somewhat } \\
\text { Disagreeable }\end{array}$ & $\begin{array}{l}\text { Somewhat } \\
\text { Agreeable }\end{array}$ & Agreeable & Very Agreeable \\
\hline O & O & O & O & O & O \\
\hline \multicolumn{6}{|c|}{ Q9. My supervisor helps me understand how my work is important to the organization. } \\
\hline $\begin{array}{c}\text { Very } \\
\text { Disagreeable }\end{array}$ & Disagreeable & $\begin{array}{c}\text { Somewhat } \\
\text { Disagreeable }\end{array}$ & $\begin{array}{l}\text { Somewhat } \\
\text { Agreeable }\end{array}$ & Agreeable & Very Agreeable \\
\hline O & O & O & O & O & $\mathrm{O}$ \\
\hline \multicolumn{6}{|c|}{ Q10. My supervisor is approachable and easy to talk to. } \\
\hline $\begin{array}{c}\text { Very } \\
\text { Disagreeable }\end{array}$ & Disagreeable & $\begin{array}{c}\text { Somewhat } \\
\text { Disagreeable }\end{array}$ & $\begin{array}{l}\text { Somewhat } \\
\text { Agreeable }\end{array}$ & Agreeable & Very Agreeable \\
\hline O & O & O & O & O & O \\
\hline \multicolumn{6}{|c|}{ Q11. My supervisor creates a motivating and energizing workplace. } \\
\hline $\begin{array}{c}\text { Very } \\
\text { Disagreeable }\end{array}$ & Disagreeable & $\begin{array}{c}\text { Somewhat } \\
\text { Disagreeable }\end{array}$ & $\begin{array}{l}\text { Somewhat } \\
\text { Agreeable }\end{array}$ & Agreeable & Very Agreeable \\
\hline O & O & O & O & O & O \\
\hline \multicolumn{6}{|c|}{ Q12. My supervisor sets high expectations for our team's performance. } \\
\hline $\begin{array}{c}\text { Very } \\
\text { Disagreeable }\end{array}$ & Disagreeable & $\begin{array}{c}\text { Somewhat } \\
\text { Disagreeable }\end{array}$ & $\begin{array}{l}\text { Somewhat } \\
\text { Agreeable }\end{array}$ & Agreeable & Very Agreeable \\
\hline O & O & O & O & O & O \\
\hline \multicolumn{6}{|c|}{ Q13. The vision and goals of this organization are important to me personally. } \\
\hline $\begin{array}{c}\text { Very } \\
\text { Disagreeable }\end{array}$ & Disagreeable & $\begin{array}{c}\text { Somewhat } \\
\text { Disagreeable }\end{array}$ & $\begin{array}{l}\text { Somewhat } \\
\text { Agreeable }\end{array}$ & Agreeable & Very Agreeable \\
\hline
\end{tabular}


“Employee engagement: An illusive force of motivation and emotional commitment of employees to the organization and its goals."

\begin{tabular}{|c|c|c|c|c|c|}
\hline O & O & O & O & O & O \\
\hline \multicolumn{6}{|c|}{ Q14. This organization provides attractive opportunities for training and development. } \\
\hline $\begin{array}{c}\text { Very } \\
\text { Disagreeable }\end{array}$ & Disagreeable & $\begin{array}{c}\text { Somewhat } \\
\text { Disagreeable }\end{array}$ & $\begin{array}{c}\text { Somewhat } \\
\text { Agreeable }\end{array}$ & Agreeable & Very Agreeable \\
\hline O & O & O & O & O & ○ \\
\hline \multicolumn{6}{|c|}{ Q15.This organization cares about employees. } \\
\hline $\begin{array}{c}\text { Very } \\
\text { Disagreeable } \\
\end{array}$ & Disagreeable & $\begin{array}{c}\text { Somewhat } \\
\text { Disagreeable }\end{array}$ & $\begin{array}{l}\text { Somewhat } \\
\text { Agreeable }\end{array}$ & Agreeable & Very Agreeable \\
\hline O & O & O & O & O & O \\
\hline \multicolumn{6}{|c|}{ Q16. I would recommend this organization as a great place to work. } \\
\hline $\begin{array}{c}\text { Very } \\
\text { Disagreeable } \\
\end{array}$ & Disagreeable & $\begin{array}{c}\text { Somewhat } \\
\text { Disagreeable }\end{array}$ & $\begin{array}{l}\text { Somewhat } \\
\text { Agreeable }\end{array}$ & Agreeable & Very Agreeable \\
\hline $\mathrm{O}$ & $\mathrm{O}$ & O & $\mathrm{O}$ & $\mathrm{O}$ & $\mathrm{O}$ \\
\hline
\end{tabular}

\section{REFERENCES}

1. Sheila Margolis, Manage cultural change using the Five Ps https://sheilamargolis.com/2014/04/11/ definition-of-employee-engagement

2. Employee Engagement-Introductionhttps://www.tutorialspoint.com/index.htm

3. http://www.meriteincentives.com/employee-recognition.php

4. Understanding Employee Engagement - Definition and its Origin,http://www.managementstudyguide. com/understanding-employee-engagement.htm

5. Examples of Employee Engagement Strategies by Ruth Mayhew, http://smallbusiness.chron.com/examplesemployee-engagement-strategies

6. How to Take Care of Employees by Charity Tober, mallbusiness.chron.com/care-employees

Citation: Dr. Almas Sabir, Dr. Arisha Fatima Rizvi. "Employee engagement: An illusive force of motivation and emotional commitment of employees to the organization and its goals." American Research Journal of Business and Management. 2018; 4(1): 1-10.

Copyright (c) 2018 Dr. Almas Sabir, Dr. Arisha Fatima Rizvi. This is an open access article distributed under the Creative Commons Attribution License, which permits unrestricted use, distribution, and reproduction in any medium, provided the original work is properly cited. 